\title{
Correction to: Livin/BIRC7 gene expression as a possible diagnostic biomarker for endometrial hyperplasia and carcinoma
}

\author{
Basma K. Elmekkawy ${ }^{1}$, Rasha M. S. Shoaib ${ }^{1}$, Amal K. Seleem², Dalia Shaalan² and Entsar A. Saad ${ }^{1 *}$ (1)
}

\section{Correction to: J Genet Eng Biotechnol 19, 1-8 (2021) \\ https://doi.org/10.1186/s43141-021-00244-w}

Following publication of the original article [1], the authors identified an error in the author name of Dalia Shaalan.

The incorrect author name is:

Dalia Shalaan

The correct author name is:

Dalia Shaalan

The author group has been updated above and the original article [1] has been corrected.

\author{
Author details \\ ${ }^{1}$ Chemistry Department, Faculty of Science, Damietta University, Mobark \\ street, New-Damietta, Damietta 34517, Egypt. ${ }^{2}$ Department of Medical \\ Biochemistry and Molecular Biology, Faculty of Medicine, Mansoura University, \\ Mansoura, Egypt.
}

Published online: 11 February 2022

\section{Reference}

1. Elmekkawy BK et al (2021) Livin/BIRC7 gene expression as a possible

diagnostic biomarker for endometrial hyperplasia and carcinoma. J Genet Eng Biotechnol 19(1):141. https://doi.org/10.1186/s43141-021-00244-w

The original article can be found online at https://doi.org/10.1186/s43141021-00244-w.

\footnotetext{
*Correspondence: entsarsaad@gmail.com; entsarsaad@du.edu.eg

${ }^{1}$ Chemistry Department, Faculty of Science, Damietta University, Mobark

street, New-Damietta, Damietta 34517, Egypt
}

Full list of author information is available at the end of the article original author(s) and the source, provide a link to the Creative Commons licence, and indicate if changes were made. The images or other third party material in this article are included in the article's Creative Commons licence, unless indicated otherwise in a credit line to the material. If material is not included in the article's Creative Commons licence and your intended use is not permitted by statutory regulation or exceeds the permitted use, you will need to obtain permission directly from the copyright holder. To view a copy of this licence, visit http://creativecommons.org/licenses/by/4.0/. 